Original Research Paper

\title{
Socio-Economic and Technical Efficiency Level of Organic Rice Farming with System of Rice Intensification: A Case Study in Morowali Regency Indonesia
}

\author{
Max Nur Alam \\ Department of Agriculture Economics, Tadulako University, Indonesia
}

Article history

Received: 27-02-2015

Revised: 26-05-2015

Accepted: 02-06-2015

E-mail: nuralam_max@yahoo.co.id

\begin{abstract}
This research aimed to (1) analyze technical efficiency level of rice farming with System of Rice Intensification and non-System of Rice Intensification and (2) analyze the factors that affected technical efficiency of rice farming. The research was conducted in Morowali Regency Indonesia. The populations in this research were farmer associations of water users, who membered as many as 104 household heads. Sampling was done by census. The number of samples that were used as many as 104 household heads, 47 household heads of rice farmers with System of Rice Intensification and 57 household heads of farmers with non-System of Rice Intensification. The result showed rice farming with System of Rice Intensification had a higher technical efficiency level when compared with rice farming with non-System of Rice Intensification. This was due to rice farming with System of Rice Intensification had more farmers who used organic fertilizers. The usage of organic fertilizers, age of farmers, education of farmers, frequency of following extension and System of Rice Intensification affected toward the technical efficiency of rice farming. Farmers could increase organic rice production with System of Rice Intensification.
\end{abstract}

Keywords: Rice, System of Rice Intensification, Organic Fertilizers

\section{Introduction}

Rice is one of the important food crops in Indonesia. The dependence on food crops, especially rice is still very large. Total calories consumed by the community in Indonesia are almost $60 \%$ that satisfied by rice (Pirngadi et al., 2002; Makarim and Suhartatik, 2006).

The achievement of rice self-sufficiency in Indonesia in 1984 was the transition of traditional farming technique (organic farming) to non-organic farming. Rice produced is the result of modern agriculture by using fertilizers and chemical pesticides. The techniques create negative impact of excessive chemicals usage. Excessive chemicals will affect the health of farmers as farming actors and farmers will have difficulty in fulfilling the input.

One of alternatives farming systems that can resolve the problem is organic farming (Sumardi et al., 2007). This alternative is very important in facing the issue of food safety. When the community became increasingly aware of the dangers of fertilizers usage and pesticides made by chemical then farming that produced healthy organic food was expected could be a solution.
Farming system that used organic materials is the System of Rice Intensification (SRI). In 1991, SRI began to be tested and applied to Asia region, this method was used to improve the state of soil fertility and rice productivity due to the saturation of the usage of fertilizers and chemical pesticides. This was proved by the results that were enough positive, namely rice that produced were about 8 tons/hectare were higher when compared with the results of national average (Pirngadi, 2009). SRI is method of rice crops cultivation by intensively, efficient and environmental friendly. SRI method is water-saving and do not use an-organic fertilizers (Ferdinan and Harmailis, 2007; Sumardi et al., 2007).

SRI technology is one of rice crops cultivation of water-saving, high yield and cost efficiency. Rice crops cultivation by organically with the usage of SRI on rice fields, will be obtained some advantages such as the usage of more efficient seeds per hectare and productions achieved will increase by $50 \%$ (Marlina et al., 2012).

SRI had been tested in more than 18 countries in the world, such as China, Cambodia, Philippine, Myanmar, Bangladesh, India, Nepal, Cuba, Indonesia and the others with results that were achieved between 7-12 
tons/ha. This system had been developed in a number of regions in Indonesia and was proved could increase rice production (Pirngadi et al., 2002; Anugrah et al., 2008).

The application of rice crop cultivation by using SRI is basically intended to obtain high production. SRI also includes cultivation system of water-saving, so it is very suitable to be applied in the irrigation area which always has a shortage of water, especially during the dry season. Rice cultivation method on SRI was expected to give a significant contribution toward production increasing and profits.

Besides the method of cultivation, the efficient of production input usage also very determines the production of rice farming (Hormozi et al., 2013; Ojogho and Alufohai, 2010; Wen et al., 2011; Maruyama et al., 2014; Watkins et al., 2014). The effort of rice production increasing through the efficiency of input usage became the right choice. Rice production is affected by agricultural land, labor, capital and management, but in practice, the factors that affect rice production can be divided into two groups, namely biological factors, such as agricultural land and fertilizers and socio-economic factors such as labor. This research aimed to (1) analyze technical efficiency level of rice farming with SRI and non-SRI and (2) analyze the socio-economic factors that affect technical efficiency of rice farming.

\section{Research Methods}

The research was conducted in Wita Ponda SubRegency Morowali Regency Indonesia. It was done because Wita Ponda Sub-Regency had applied SRI pattern in organic rice farming. The populations in this research were farmer associations of water users in Wita Ponda Sub-Regency. Associations of water users had members as many as 104 Household Heads (HH), but from all of associations of water users members were not entirely applied SRI pattern in their farming. Considered the condition, then the determination of respondent in this research was done by census method. Farmers of associations of water users members amounted $104 \mathrm{HH}$ that consisted of $47 \mathrm{HH}$ who applied SRI and $57 \mathrm{HH}$ who applied non-SRI.

The stochastic frontier production function was used to answer the first objective. This function is based on the model that developed by Coelli et al. (2005):

$\ln Y_{i}=\lambda_{0}+\sum_{j=1}^{k} \lambda_{j} \ln X_{j i}+\left(V_{i}-U_{i}\right)$

The production function was assumed to have a Cobb-Douglas form who transformed into natural logarithm form:

$$
\begin{aligned}
& \ln Y=\lambda_{0}+\lambda_{1} \ln B N H \\
& +\lambda_{2} \ln P U K+\lambda_{3} \text { Pest }+\lambda_{4} \ln T K+\left(V_{i}+U_{i}\right)
\end{aligned}
$$

Where :

$\mathrm{Y} \quad=$ Rice production $(\mathrm{kg})$

$\mathrm{BNH}=$ Seed $(\mathrm{kg})$

PUK $=$ Fertilizers $(\mathrm{kg})$

Pest $=$ Pesticides (liter)

$\mathrm{TK}=$ Labor $(\mathrm{HOK})$

$\mathrm{V}_{\mathrm{i}} \quad=$ Error of random model

$\mathrm{U}_{\mathrm{i}}=$ Random variable that presented the inefficiency of i sample technical

Technical efficiency level of rice farming was estimated by the formula of (Coelli et al., 2005):

$T E_{i}=\frac{y_{i}}{y_{i}^{*}}=\frac{\exp \left(x_{i} \beta+v_{i}-u_{i}\right)}{\exp \left(x_{i} \beta+v_{i}\right)}=\exp \left(-u_{i}\right)$

Where:

$y_{i}=$ Actual production

$y_{i}^{*}=$ Alleged of frontier production

Multiple linear regression model was used to answer the second objective:

$T E_{i}=\delta_{0}+\delta_{1} X_{1}+\delta_{2} X_{2}+\delta_{3} D_{1}+\delta_{4} D_{2}+\delta_{5} D_{3}+\mu_{\mathrm{i}}$

Where:

$\mathrm{TE}_{\mathrm{i}}=$ Technical efficiency that was estimated;

$\delta_{1}-\delta_{5}=$ Regression coefficient

$\mathrm{X}_{1} \quad=$ Age of respondent

$\mathrm{X}_{2}=$ Frequency of following agricultural extension;

$\mathrm{D}_{1} \quad=$ Dummy education

$\mathrm{D}=0$ for farmers who did not graduate from elementary school

$\mathrm{D}=1$ for other farmers

$\mathrm{D}_{2}=$ Dummy organic

$\mathrm{D}=0$ for farmers without organic

$\mathrm{D}=1$ for farmers used organic

$\mathrm{D}_{3} \quad=$ dummy SRI

$\mathrm{D}=0$ for non-SRI farmers

$\mathrm{D}=1$ for SRI farmers

$\mu_{\mathrm{i}} \quad=$ error term

\section{Results}

\section{Technical Efficiency Level}

Technical efficiency of rice farming in this research used the stochastic frontier production function. This analysis was used to measure the technical efficiency level of rice farming with SRI and non-SRI. The form of production function that used was Cobb Douglas Stochastic Frontier. This production function is taken on 
Education is the main modal in analyzing a job, so that farmers can streamline production factors used. The usage efficiency of production factors can reduce the cost of production so that income of farmers can increase.

Frequency of following extension affected positive and significant toward technical efficiency level of rice farming at confidence level $99 \%$. Following extension could reduce inefficiencies of farmers in rice farming. It was strengthened by research of (Lawal et al., 2014; Islam et al., 2012; Ogisi et al., 2012). Extension is one of innovation diffusion ways, so that farmers who were often followed the extension been expected could adopt the innovation which recommended in order of increasing their farming production.

The usage of organic fertilizers affected positive and significant toward technical efficiency level of rice farming at confidence level $99 \%$. The usage of organic fertilizers could reduce inefficiencies of farmers in rice farming. This is due to the organic materials serve as soil and supplement of synthetic chemical fertilizers (Las et al., 2006). The Sustainability of high efficiency would depend on the continued support which farmers received in the field of inputs providing (Donkoh et al., 2013).

Cropping rice with SRI affected positive and significant toward technical efficiency level of rice farming at confidence level $99 \%$. SRI could reduce inefficiencies of farmers in rice farming. This was due to most of SRI farmers used semi-organic input. Organic SRI can restore the state of soil fertility and rice productivity due to the saturation of fertilizers usage and chemical pesticides (Pirngadi, 2009).

\section{Conclusion}

SRI rice farming had a higher technical efficiency level when compared with non-SRI rice farming. This was due to SRI rice farming had more farmers who used organic fertilizers. Partially age of farmers, education of farmers, frequency of following extension, usage of organic fertilizers and SRI affected toward technical efficiency of rice farming. Farmers could increase rice production with organic SRI.

\section{Acknowledgement}

The author would like to thank Prof. Dr. Ir. Muhammad Basir, SE., MS and Prof. Dr. Ir. Made Antara, MP who had guided and directed the author. The author also liked to thank the reviewers so this paper could be published.

\section{Funding Information}

This article was funded by the University of Tadulako. The funders had no role in study design, data collection and analysis, decision to publish, or preparation of the manuscript.

\section{Ethics}

This article is original and contains unpublished material.

\section{References}

Anugrah, I.S., Sumedi and D.I.P. Wardana, 2008. Gagasan dan Implementasi System of Rice Intenfication (SRI) dalam Kegiatan Budidaya Padi Ekologis (BPE). Analisis Kebijakan Pertanian, 6: 75-79.

Balde, B.S., H. Kobayashi, M. Nohmi, A. Ishida and M. Esham et al., 2014. An analysis of technical efficiency of mangrove rice production in the Guinean coastal area. J. Agric. Sci., 6: 179-196. DOI: $10.5539 /$ jas.v6n8p179

Coelli, T.J., D.S.P. Rao, C.J. O'Donnell and G.E. Battese, 2005. An Introduction to Efficiency and Productivity Analysis. 1st Edn., Springer Science and Business Media, New York, ISBN-10: 0387242651, pp: 349.

Debertin, D.L., 1986. Agricultural Production Economics. 2nd Edn., CreateSpace Independent Publishing Platform, Lexington, ISBN-10: 1469960648, pp: 428.

Donkoh, S.A., S. Ayambila and S. Abdulai, 2013. Technical efficiency of rice production at the tono irrigation scheme in northern Ghana. Am. J. Experim. Agric., 3: 25-42. DOI: $10.9734 / A J E A / 2013 / 1448$

Ferdinan and Harmailis, 2007. Aplikasi sistem intensifikasi padi (SRI) untuk efisiensi penggunaan air dan meningkatkan produksi padi sawah. J. Penelitian Lumbung Univ. Andalas, 6: 838-845.

Hormozi, M.A., M.A. Asoodar, A. Abdeshahi and D.C. Baruah, 2013. The role of water pumping in energy efficiency of rice cropping systems in khuzestan province, Iran. Int. J. Agric. Res. Rev., 3: 96-102.

Islam, K.M.Z., J. Sumelius and S. Bäckman, 2012. Do differences in technical efficiency explain the adoption rate of HYV rice?: Evidence from Bangladesh. Agric. Econom. Rev., 13: 93-110.

Las, I., K. Subagyono and A.P. Setiyanto, 2006. Isu dan pengelolaan lingkungan dalam revitalisasi pertanian. J. Litbang Pertanian, 25: 106-114.

Lawal, A.F., A. Liman, D.A. Ibrahim and L.T. Yusuf, 2014. Technical inefficiency and sustainability of rice production in the fadama of Niger state, Southern Guinea Savanna of Nigeria. Ind. J. L. Sci., 3: 15-25.

Mailena, L., M.N. Shamsudin, Radam and I. Latief, 2014a. Rice farms efficiency and factors affecting the efficiency in MADA Malaysia. J. Applied Sci., 14: 2177-2182. DOI: 10.3923/jas.2014.2177.2182 
Mailena, L., M.N. Shamsudin, A. Radam and Z. Mohamed, 2014b. Efficiency of rice farms and its determinants: Application of stochastic frontier analysis. Trends Applied Sci. Res., 9: 360-371.

DOI: $10.3923 /$ tasr.2014.360.371

Makarim, A.K. and E. Suhartatik, 2006. Budidaya padi dengan masukan in situ menuju perpadian masa depan. Buletin Iptek Tanaman Pangan. Depart. Pertanian, 1: 19-29.

Marlina, N., E.A. Saputro and N. Amir, 2012. The response of rice (Oryza sativa L.) to organic fertilizer plus and organic pesticides under the System of Rice Intensification (SRI) in Tidal Lowlands. J. Lahan Suboptimal, 1: 138-148.

Maruyama, A., Y. Haneishi, S.E. Okello, G. Asea and T. Tsuboi, 2014. Rice green revolution and climatic change in east Africa: An approach from the technical efficiency of rainfed rice farmers in Uganda. Agric. Sci., 5: 330-341. DOI: $10.4236 /$ as.2014.54035

Ogisi, O.D., C.O. Chukwuji and D.C. Okeke, 2012. Efficiency of resource use by rice farmers in Ebonyi State, South East Nigeria: A data envelopment analysis. Asian J. Agric. Rural Develop., 2: 149-154.

Ogundari, K., T.T. Amos and S.O. Ojo, 2010. Estimating confidence intervals for technical efficiency of rainfed rice farming system in Nigeria. China Agric. Econom. Rev., 2: 107-118. DOI: $10.1108 / 17561371011017531$

Ojogho, O. and G.O. Alufohai, 2010. Economies of scale and production efficiency in smallscale rice farmers in Nigeria: empirical approach for hybrid and local rice. Global J. Agric. Sci., 9: 31-36.

DOI: 10.4314 /gjass.v9i1.62785
Pirngadi, K., 2009. Peran bahan organik dalam peningkatan produksi padi berkelanjutan mendukung ketahanan pangan nasional. Pengembangan Inovasi Pertanian, 2: 48-59.

Pirngadi, K., O. Syahroni and T.S. Kadir, 2002. Model pengelolaan tanaman padi pada lahan sawah beririgasi. J. Agrivigor Univ. Hasanudin, 2: 84-96.

Piya, S., A. Kiminami and H. Yagi, 2012. Comparing the technical efficiency of rice farms in urban and rural areas: A case study from Nepal. Trends Agric. Econom., 5: 48-60. DOI: 10.3923/tae.2012.48.60

Sumardi, M. Kasim, S. Auzar and N. Akhir, 2007. Respon padi pada teknik budidaya secara aerobik dan pemberian bahan organik. J. Agrosia Univ. Bengkulu, 10: 65-71.

Watkins, K.B., T. Hristovska, R. Mazzanti, C.E. Jr. Wilson and L. Schmidt, 2014. Measurement of technical, allocative, economic and scale efficiency of rice production in Arkansas using data envelopment analysis. J. Agric. Applied Econom., 46: 89-106.

Wen, G.F., S. Sizhong and Y.Z. Zhang, 2011. Technical efficiency of food processing in China: The case of flour and rice processing. China Agric. Econom. Rev., 3: 321-334. DOI: $10.1108 / 17561371111165761$ 